\title{
Plagiarism in Kosovo: a case study of two public universities
}

\author{
Sabiha Shala ${ }^{1} \mathbb{D}$, Dukagjin Leka $^{2^{*}}$ and Tina Morganella ${ }^{1}$
}

\author{
* Correspondence: \\ dukagjin.leka@uni-gjilan.net \\ ${ }^{2}$ University of Kadri Zeka, Gjilan, \\ Kosovo, Albania \\ Full list of author information is \\ available at the end of the article
}

\begin{abstract}
This article presents the current legislative and educative measures in place for plagiarism prevention in Kosovo, especially in the case of student work, and provides an analysis of the effectiveness of such measures. Two public universities are used as case studies - the University of Haxhi Zeka and the University of Kadri Zeka - and the research is based on the legal and policy documents enacted by the two universities, as well as many reports, scientific articles on plagiarism and HEl official websites. The issue of plagiarism has only recently become a priority in Kosovo, with many factors hindering advancement and development in this area.
\end{abstract}

Keywords: Higher education, Kosovo, Plagiarism

\section{Introduction}

Until recently, plagiarism received little attention in Kosovo. Only 20 years ago, Kosovo was heavily occupied with politics and war, and plagiarism was understandably considered insignificant in comparison. The situation has started to change, however, and many positive moves have been made to prevent and combat plagiarism, such as the Government's new copyright legislature. The lack of law implementation and adherence, however, is making it difficult to achieve positive results. Previous research shows that the perception of corruption in Higher Education Institutions (HEIs), is similar to the overall perception of corruption in Kosovo (Berisha 2014). This perception tells us a lot about the culture and tradition of the society, and although it may be true to some extent, it is very difficult to change the situation quickly. The perception that all professors are corrupt remains only a perception and not something that can be ultimately proved. There are individual cases of corruption, but attempting to generalise about this does not lead to any positive developments in this regard.

The main aim of the present article is to present the current legislative and educative measures that are already in place for plagiarism prevention in student's written work, and to analyse the implementation of such measures. Two public universities are used as case studies - the University of Haxhi Zeka (UHZ) and the University of Kadri Zeka (UKZ) - and the research is based on the legal and policy documents enacted by the Kosovo Government and Parliament, by the two universities, as well as many reports, scientific articles on plagiarism, etc. All seven public universities in Kosovo have their own statutes, three of which are approved by the Assembly of the Republic of Kosovo (SUHZ 2013, SUPZ 2013, SUP 2013), and four in the form of Temporary Statutes by

(c) The Author(s). 2018 Open Access This article is distributed under the terms of the Creative Commons Attribution 4.0 International License (http://creativecommons.org/licenses/by/4.0/), which permits unrestricted use, distribution, and reproduction in any medium, provided you give appropriate credit to the original author(s) and the source, provide a link to the Creative Commons license, and indicate if changes were made. 
the Minister of Education, Science Technology (TSUKZ 2013, TSPUM 2013, TSPUGJ 2013, TSUASF 2015). With regard to the two universities under analysis here, UHZ in Peja functions with a statute that was approved by the Assembly in 2013, and UKZ in Gjilan operates under a temporary statute signed by the Minister of Education in 2013. Prior to the analysis, some introductory points on the higher education system in Kosovo will be presented.

\section{Literature review}

\section{The higher education sector in Kosovo}

The right to education is a constitutional right in Kosovo and as such is guaranteed by Article 47 of the Constitution of the Republic of Kosovo (CRK 2008). The Higher Education sector in Kosovo is regulated by the Law on Higher Education (LHE 2011). Kosovo has 30 HEIs (KAA 2018a) - 9 are public HEIs, and 21 are private HEIs (colleges, institutes, higher professional schools and academies). All have been established based on applicable legislation and by legal institutions (KAA 2018a). Both public universities and private HEIs provide academic and professional higher education study programmes as well as scientific and research activities. Private HEIs provide mostly bachelor and master's degrees, and do not offer studies at PhD level (LHE 2011, AIAHEI 2017). In the academic year 2017/18 around 110,205 students studied in Kosovo. Of these students, 70,381 (or 71\%) studied in public HEIs, and 39,824 (or 29\%) in private HEIs (MEST 2018). In the same year, 96,934 students undertook bachelor level programmes (87.95\%), 13,271 undertook master's level programmes (12\%), and only 64 undertook doctoral level programmes (0.05\%) (MEST 2018).

The number of international students in Kosovo is very low. In the academic year 2017/ 18, there were 657 foreign students from regional countries, Turkey and other countries (MEST 2018). The most popular subjects among foreign students are medicine, philosophy, law, and engineering (MEST 2018). In 2016, the MEST enacted the new Strategy on Education that makes it easier for universities to attract foreign students in the future (SPHE 2016). Joint study programmes with international universities issuing joint degrees are foreseen under this strategy. With this strategy in mind, for the first time in Kosovo three public universities - UKZ, UHZ and the University Ukshin Hoti - managed to gain accreditation for one joint master's degree (KAA 2018b). This degree has started to attract foreign professors and encourages further cooperation with international universities. Ideally, joint programs, especially $\mathrm{PhD}$ programs, which could not be organised otherwise, can be developed with this international cooperation. An increase of international students is also seen through participation of HEIs in different international projects, like Erasmus +, Ceepus, Horizon 2020, etc., which provides mobility opportunities for academics, students and administrative staff as well.

Kosovo is currently just an observer of the Working Group of the Bologna Process (SPHERE 2018), and not yet an official member. But, since 2002, institutions have developed national legislation in compliance with the Bologna Process in order to make it easier to implement and operationalise its reforms, objectives and principles within higher education systems in Kosovo. Also since 2002, statutes have been ratified for six newly established public universities: Mitrovica, Peja, Prizren, Gjilan, Gjakova and Ferizaj (SUHZ 2013, SUPZ 2013; TSUKZ 2013, TSPUM 2013, TSUGJ 2013, TSUASF 2015). The new statute of the University of Prishtina, the new draft Law on Higher 
Education, and the Law on Regulated Professions were approved too (UP 2004, SUP 2013; LHE 2011, LRPRK 2016). With the support of European Union projects, the Kosovo Student Union has also been established and functionalised (SPHERE 2018). As a result of such actions, all HEIs in Kosovo currently implement the European Credit Transfer and Accumulation System (ECTS), the three-cycle degree system, student and staff mobility, the diploma supplement and a quality assurance system. In the last two years, public universities supported by international projects have started to develop a Diploma Supplement as requested by the Bologna Process (SPHERE 2018). Even though HEIs in Kosovo have already established internal quality assurance systems, they continue to further strengthen them.

The accreditation process of HEIs and study programmes started in 2008, when the Kosovo Accreditation Agency (KAA) was established. In 2014, the KAA became a member of the European Network of Quality Assurance (ENQA) in higher education (ENQA 2014). The membership was approved because the General Assembly of ENQA was convinced that KAA could enforce and respects the European Standard Guidelines regarding external quality assurance (SPHERE 2018). In September 2017, however, the new Minister of Education, Science and Technology dismissed the Board and Director of the KAA, and as a result the General Assembly of ENQA suspended KAA's full membership. Since July 2018, KAA has become a member under review (ENQA 2018).

With regard to financial aspects, it is worth mentioning that public HEIs are financed by the state and only the University of Prishtina is an independent financial organisation able to manage with its own revenue, while all private HEIs are self-financed. Currently, the MEST, in cooperation with international and national partners (HEIs), is developing a framework for a standardised and unified financial management practice for all public institutions, and they intend to include these standards in the new law on higher education (FAITH 2016).

Some of these positive developments, challenges and priorities mentioned above might be addressed via the reforms on information and communication technologies. MEST, with the support of foreign donors, has developed and will start implementing the Platform for ICT Data System Management. However, the lack of coordination on planning, setting priorities and monitoring continues to remain a challenge among HEIs and MEST (SPHERE 2018).

\section{Quality assurance on teaching, learning and assessment}

The basic law regulating the use of intellectual property in Kosovo is the Law on Copyright and related rights, the first version of which was adopted on 4th of April 2007 (LCRR 2007). This law was abolished by the new Law on Copyright and related rights in 2011 (LCRR 2011) and was amended again in 2016 (LCRR 2016). According to Article 8 of this law, the works of the author in particular are protected and considered:

a) verbal Works (such as speeches, lectures, narratives and other similar works represented verbally); b) written works (textbooks, brochures, daily newspapers, and other texts of the literary domain, scientific and professional literature as well as computer programmes; c) music works with or without text; d) theatrical Works; e) 
choreographic and pantomime works; f) filmic and other audio-visual Works: $g$ ) photographic works and other related Works; h) art works in the area of painting, sculpture, graphics and drawing; i) architectural works (charts, plans, templates and the buildings built based on architectural and engineering works, urbanism, panorama and interior design); j) stenography works; $k$ ) applicative art works as well as industrial and graphic design; l) cartographic works in the area of geography and topography; $m$ ) scientific, educational or technical presentations (LCRR 2011; LCRR 2016, Art. 3).

Article 1 of the Law on Higher Education establishes a legal base for ensuring that quality assurance and operationalization of higher education system in Kosovo complies with European standards. The Law guarantees that HEIs have autonomy and academic freedom, and defines the autonomy by specifying rights to:

a) elect governing and management authorities and determine their mandates; $b$ ) arrange their structures and activities through their own rules in conformity with this Law and with other applicable laws and their statutes; c) choose teaching and other staff, set conditions for admission of students and methods of teaching and evaluation of students, as approved by KAA; d) independently develop and implement curricula and scientific research projects, in consultation with international and domestic partners; and) grant titles to professors and other staff, in accordance with this law, with applicable law and employment scheme has been approved by KAA (LHE 2011, Art.13).

Based on the Law on Higher Education and its derivative sub-legal acts, HEIs in Kosovo are obliged to regulate their internal quality assurance systems through their Statute and internal regulations. HEIs are responsible for creating and implementing study programmes and have to provide regular self-assessment to KAA and improve internal structures for quality assurance based on KAA requirements. UKZ and UHZ have both prepared and issued the necessary documents with regard to protecting academic ethics and combatting corruption. They have both enacted a Code of Ethics (CoE), operationalised as legal documents and through which they are attempting to regulate the unethical academic issues within their institutions. It is worth mentioning that having a CoE and fully implementing it are two separated matters, especially in a country like Kosovo. Unfortunately, implementation is difficult due to many reasons. For example, students in Kosovo, like students around the world, have been caught cheating on exams. But even when, for example at UKZ, when students have been caught cheating with their mobile phones, the responsible parties within the faculty have not dealt with the matter effectively. At UHZ the implemented measures have been more effective in this regard - over the last two years reported cases have been addressed at the Disciplinary Committee who have then imposed measures against the offender, such as the suspension of studies from 6 months to 1 year.

\section{Plagiarism and potential corruptive behaviours in Kosovo}

According to Masic (2012), the origin of the term plagiarism is from the Latin word plagium, meaning to kidnap a man, and literally means theft - to take material authored by another and present it as your own (Okoche and Michael 2013). Much has been written about plagiarism and many comprehensive definitions have been developed (Masic 
2012; Okoche and Michael 2013; Vinod et al. 2011; Wager 2014). However, there are many scholars who think that it is impossible to have a single definition and instead describe different types of plagiarism. Indeed, an understanding of plagiarism differs even within Kosovo, and government and university policies vary from one another. Plagiarism is not a new phenomenon in academic circles but it has received little attention or priority in Kosovo for various reasons. Historically and culturally, it has been common practice to ignore friends' and colleagues' unethical behaviours in their academic and scientific work (Craig and Dalton 2014).

Today, technology has allowed an enormous increase in accessing the scientific work of other scholars but this access is a double-edged sword (Embleton and Helfer 2007). Information is not always used in an ethical way, and some students, intentionally or unintentionally, are using text or data without referencing the original source (Guraya and Guraya 2017). The same situation stands in Kosovo. As Vinod et al. (2011) states, some researchers and students may be committing plagiarism inadvertently. It is very important to mention that in Kosovo there is no single source of information that students can go to, to learn about plagiarism. Recently, HEIs have started to include Academic Writing or Ethics in Writing as mandatory subjects in study programs to educate students. In the researchers' experiences, students have plagiarised because they lacked information and knowledge. Nevertheless, plagiarism is sanctioned and prohibited through legal acts and institutional regulations in Kosovo, and all public universities in Kosovo are trying to deter these very harmful, unethical academic behaviours and illegal activities. Part of the Law on Copyright and Related Rights (2011, 2016) addresses plagiarism, but it is important to analyse if this law and other legal acts for deterring plagiarism are complete and really protect authors' rights. The following sub-section will present and analyse such policies and regulations.

\section{Plagiarism policies and regulations}

Plagiarism does not know borders and cases of plagiarism can be found all over the world (Annane and Annan 2012; Bailey 2016). However, plagiarism seems to be more pronounced in countries that, like Kosovo, have poor legal regulations on copyright, incomplete or weak ethical norms (Annane and Annane 2012), and a lack of policies and procedures on plagiarism prevention. The law on Copyright and Related Rights (LCRR 2016, LCRR 2011) does not contain any direct reference to plagiarism but it prohibits it indirectly by elaborating the right of the author. Moreover, this law is focused mostly on the protection of artistic output, which is understandable as the Ministry of Culture, Youth and Sports developed and sponsored the statute. The Law on Higher Education in Kosovo (LHE 2011) does not define plagiarism at all, leaving HIEs with the authority to regulate student assessment criteria and plagiarism prevention measures through their statutes, internal regulations and code of ethics (Article 27).

The statutes of UHZ and UKZ do not define the term "plagiarism" at all. The statute of UHZ does stipulate withdrawal of a doctoral title if the candidate has plagiarised (Article 126), but neither statutes sanction directly bachelor and master's degrees students who plagiarise. They only indirectly require students to respect the CoE (TSUKZ 2013, Article 128, paragraph 1.6, SUHZ 2013). Universities, on the basis of their statutes, are obliged to issue codes of ethics and internal regulations for studies 
and disciplinary procedures. Both UHZ and UKZ have a CoE in force which defines in some way the term "plagiarism". However, the terms of plagiarism, the mechanism for implementing the $\mathrm{CoE}$, as well as the sanctions against academics and students who plagiarise, differ from one university to another.

Article 3 of the UKZ CoE provides that, "Plagiarism means the act of appropriating or copying the idea, the results, the writing or any other form in whole or in part, without indicating the source used and without any merit for the same." (RCE 2016). As far as the implementing mechanisms of UKZ's CoE is concerned, the Ethics Council is responsible for dealing with academic staff violations of the CoE, whereas the Disciplinary Commission, established within the academic units, address student violations of the CoE standards. The Code allows the Disciplinary Committee to develop procedures and functions on the basis of regulations of academic units, but does not allow for any disciplinary measures or sanctions for students who violate the CoE. The Disciplinary Committee should be allowed to develop procedures and impose penalties in accordance with the Regulation on Disciplinary Proceedings.

Currently, the UKZ Senate has issued a Regulation on disciplinary procedures at university level (RMDP 2014), and its article 8 considers the violation of the CoE by the academic staff, but not the students, as a serious violation (Article 13 \& 14). The bachelor degree regulations of the UKZ's academic units incorporate Article 110 of the university's Statute in its two articles. Article 50 of the regulation stipulates that:

In the final exam (diploma), the student must demonstrate the theoretical and theoretical abilities that the student has achieved during his studies, in the acquisition of the subject, that the subject has worked with the method that corresponds knowing the literature and knowing how to use it professionally and independently (RBS 2013).

Whereas Article 49, paragraph 1 provides that the:

Bachelor's Degree is individually worked by the student, proving that the theoretical abilities achieved during the study period can be successfully exploited to solve practical problems in certain scientific fields. (RBS 2013).

Neither of these articles contribute to the prevention of plagiarism committed by students as they are very general and not very useful in helping students to understand clearly through which actions plagiarism has occurred. In addition, the Regulation on Disciplinary Procedures does not consider the breach of the CoE as an offence.

The UHZ CoE, unlike the UKZ CoE, provides a more complete definition of plagiarism. Article 23 of this Code states that, "Plagiarism is the use of words, ideas, concepts or data of another person without quoting." This article further explains situations when plagiarism may occur: "Plagiarism may exist in circumstances where the student says that he / she is the original source of information. Plagiarism involves the direct use and paraphrase of other words, thoughts or concepts without quoting." According to the same article, plagiarism includes but is not limited to: 
a. unpatched copying of passages from electronic works and / or copies of works of others in homework or course, essay, scientific work, or thesis;

$b$. use without showing the views, opinions, or knowledge of another person;

c. paraphrasing without showing the phraseology, original characteristics, metaphor of another person, or other literary projects.

The Code obliges students to make full citations, and for anything that is not regulated by this CoE regarding plagiarism, legal provisions of the Copyright Law and Other Approximate Rights and Internal Regulations of the UHZ may be applied instead (CE 2014, Article 23). A Council of Ethics has already been established by UHZ to implement the CoE. In the case of plagiarism by students, Article 25 of this Code states the penalty as "O (zero) point on semester assignments, annulment of plagiarism and suspension for a period of defence of the subject in $B A, M A$ or dissertation up to making a decision." It is worth mentioning that UHZ's Disciplinary Procedural Regulation considers the violation of the $\mathrm{CoE}$ as a serious violation if committed by academic staff (Article 8) but not if it committed by students, not even as a soft violation (Article 16).

The UHZ Senate has issued three regulations for bachelor, master and doctoral studies. While the Regulation for Bachelor Studies (RBS 2016) does not contain any provision on plagiarism prevention, the Regulation for Master studies, under Article 45 (RMS 2016), states that, "Master title of a candidate for master may be challenged and taken over if it is ascertained that master thesis is plagiarized or is a forgery." The same article also defines the procedures for withdrawal. As for the Regulation for Doctoral Studies (RDS 2017), it states that the doctoral degree must be an original work, and regulates the preparation process and the defence of the thesis, but it does not refer at all to the term "plagiarism". However, the Statute does stipulate the withdrawal of a $\mathrm{PhD}$ title in the case of plagiarism. Few faculties ask students to include in their thesis a signed declaration specifying that the work was done by the student themselves, and that rules on authorship have been respected, etc. Neither university has so far prepared a good general methodological guideline for the preparation of Bachelor, Master or $\mathrm{PhD}$ theses, which should include detailed guidance on how to quote works of other authors in their written works, etc.

\section{Implementation of measures for plagiarism prevention}

The responsibility of these universities is to establish mechanisms and determine proper channels to deal with plagiarism prevention and deterrence. As stated above, to date only the UHZ has an institutional mechanism, the Commission of Ethics, tasked to deal with the implementation of plagiarism prevention measures provided in the CoE. This Commission has very recently been established and so far has only dealt with two cases, neither of which were directly related to plagiarism. The UKZ has not yet established such a Commission, and cases of plagiarism committed by students of this university are overseen by the Disciplinary Commission established at the academic unit or faculty level. These disciplinary commissions are established within the faculties but so far they have not dealt with any cases related to plagiarism.

Neither university requires their students to sign a written contract - the "University anti-plagiarism charter" - against plagiarism, as is the case in some other countries (Annane and Annane 2012). Each professor includes in their syllabus the general rules 
on the CoE inquiring students to respect them but this part is very general and not only for plagiarism (UKZ 2018a, UHZ 2018a). Anecdotal evidence ${ }^{1}$ gathered through conversations with the managerial staff of these universities suggests that no cases have so far been reported for plagiarism, and the council of faculties did not treat any case which ended in the cancelation of a Bachelor or Master's degree due to plagiarism.

\section{Teaching and training on academic writing}

Both UHZ and UKZ include courses on academic writing and research methodology in degree studies. These courses include topics on literature searches, correct citing, referencing and academic integrity, etc. This course is compulsory in some programs and an elective in others. In some programs, the course is offered to all first year, first semester, bachelor and master's students, but in some other programs it is offered in the last year of study in the first semester (UHZ 2018b; UKZ 2018b).

With regard to training on citing and paraphrasing scientific texts, so far neither of the universities has done that for their students. UHZ did provide such training to their academic staff only in July 2018. Together, UHZ and UKZ, in cooperation with the Council of Europe, are trying to implement one training program for the academic staff of both universities about plagiarism and predatory journals.

\section{Digital tools used for detecting plagiarised text and repositories}

Neither university use any specialised digital tools for detecting plagiarism in students' written works, despite the fact that the CoE obliges UHZ to provide software that automatically looks for plagiarism via research papers and other publications (CE 2014, Article 23). Informal interviews with the managerial staff of the universities reveal that some teachers are planning to use the software program Plagiarism Detector, which compares uploaded document with others previously published and available online. But, when it comes Kosovo, there are thousands of Master and Bachelor theses which are not published anywhere, and which makes the process of verification much harder. Other UHZ and UKZ teachers are using Google tools for information searches on the Internet using keywords or specific phrases. These tools are not very convenient but do allow teachers to find potentially plagiarised documents, stored in open access databases or websites of HEIs or other institutions.

Discussions about the possibility of buying the software program Turnitin https:// www.turnitin.com (Okoche and Michael 2013) are ongoing between Kosovo HEIs and the MEST during the events organised by international organisations (Council of Europe 2017). In the meantime, some universities are in discussions with an organization that is developing an Albanian-specific Anti-Plagiarism Software, expected to be financed by MEST. One problem raised by academic staff is the issue of language - if the research work of Kosovar students is in Albanian, would software detect plagiarism in the case where text has been translated from English to Albanian, or from other languages to Albanian. The language problem has been discussed in other countries and for other languages as well. Wager (2014) considered this problem while defining the term plagiarism. According to him the plagiarised tables or figures, ideas, or plagiarism in translation cannot be detected by anti-plagiarism software as these software programs only detect the extent of text copied. 
It is also important to mention the limited opportunities students have to access online or printed versions of foreign literature in Kosovo. MEST financed the access fee for the EBSCO database for all public universities (Buja 2013) for all students and academic staff, but based on communication with MEST staff, the percentage of use by the academic staff and students from the universities was very low. One of the reasons for this very low access to EBSCO might be the lack of knowledge of English by the students. It should also be noted that universities have insufficient funding to acquire foreign literature.

With regard to accessing the national literature in Kosovo, in the Albanian language, HEIs are obliged to keep in their libraries both hard and electronic copies of bachelor and master theses (and Phd theses for those universities that offer those programmes), and deposit an electronic copy of these theses in the National Library of Kosovo (NLK 2018). Even though the library conditions need to be improved, this national depository can help academic staff prevent students trying to plagiarise written works prepared by students from other universities in Kosovo.

\section{Discussion and recommendations}

Currently, neither UKZ nor UHZ can offer students and staff a clear definition of plagiarism, the detailed requirements for preparation of a thesis, or the detailed requirements for citing and referencing. With regard to the definition of plagiarism, it is very important to find its limits. A CoE only provides a vague definition and a very limited measure for detecting and deterring plagiarism. Unclear, weak and incomplete policies and regulations may encourage students of these universities to plagiarise, intentionally or unintentionally. According to Comas and Sureda (2010), HEIs should apply more punitive measures in combatting plagiarism by taking the role of a judge, a policeman and an educator. But Guraya and Guraya (2017) argue the opposite because, according to them, a great majority of cases of plagiarism are unintentional and accidental, and punitive measures are not helpful in solving such problems.

Despite existing legal obligations, due to financial limitations both UKZ and UHZ lack the appropriate digital tools for detecting plagiarism. It is expected that MEST will pay for digital tools such as Turnitin. The use of digital tools or computer software to help prevent plagiarism prevention is considered by many people as a good solution to the problematic issue (Comas and Sureda 2010). However, Guraya and Guraya (2017) think that educative measures are still more effective then digital tools. With regard to educative measures, both UKZ and UHZ do offer courses on academic writing but neither effectively educates students on methods of referencing and citing, and the consequences of plagiarism. Nor is training on new methods of preventing plagiarism organised for academic staff. It seems that educating students is the best tool for plagiarism prevention (Stabingisa et al. 2014 p.692). Carroll and Appleton (2001, Carroll 2004) subdivide these measures as follows: a) removing possibilities to plagiarise (for example, via creative preparation of study tasks and evaluation); b) informing students about institutional policy and procedures concerning plagiarism; c) teaching students about plagiarism and how to avoid it; d) creating a culture of intolerance to plagiarism; e) legal and proper use of computer tools for plagiarism searches; f) clear distinction between assessment of students and disciplinary processes; g) clear, true and consistent disciplinary procedures; and h) common responsibility of all persons, implementing 
plagiarism prevention policy and performing procedures. Atkinson and Yeoh (2008) summarised these measures in a different way, classifying them based on three elements of plagiarism prevention mechanisms: teaching preventative measures, detecting plagiarism, and punishing those committing plagiarism.

Considering the issues above, the authors believe that Kosovo should urgently focus more on improving and implementing legislation, and take adequate measures against those who plagiarise. Based on the analysed documents, interviews, survey results and experience of other countries that may be relevant for Kosovo (Latvia, Lithuania, Australia), the following recommendations have been identified. A large number of recommendations are based on a holistic approach (Stabingis et al. 2014). The following measures are divided into three levels of classification, as suggested by Stabingis et al. (2014):

\section{National level (parliament, government, MEST, and National Library in Kosovo)}

a. The National Library of Kosovo's repositories for collection and storage of students' written works (bachelor, master and $\mathrm{PhD}$ theses) need to be better maintained, and building conditions need to be improved to ensure easier access for the HEIs.

b. Legal regulations for encouraging the development and use of digital text matching tools in HEIs should be put in place by the MEST. Moreover, all HEIs in Kosovo should be required to collect and upload student work for checking against other work in their repository. This will contribute to the prevention of students resubmitting work prepared by students in other HEIs as their own work and passing the exams.

c. In the longer term, Kosovo should develop digital tools in Albanian in order to enable matches against papers in other languages and internet-based resources.

d. MEST and the Kosovo Agency for Accreditation should develop clear guidelines for institutions with regard to what constitutes effective policies for upholding academic integrity.

\section{Institutional level}

a. It is recommended that universities develop clearer and more detailed legislation and policies against plagiarism, and implement clearer procedures for fair handling of allegations, oversight and punishment of plagiarism, as well as procedures for hearing student appeals. With regard to the definition of plagiarism, it is very important to find its limits. One good model of plagiarism definition is the model proposed by Lindsay (2016, p.27) who argued that, "The model of plagiarism as a disciplinary concept should be limited to circumstances where student conduct amounts to intentional or negligent breaches of relevant academic conventions."

b. All information regarding plagiarism, procedures, measures and other relevant information should be accessible for everyone in the university.

c. Universities in Kosovo need to organise discussions, with the participation of academic staff and motivated students, about improving academic writing, citing 
and referencing and understanding the essence of formal requirements. University administration should educate personnel in methods for discouraging plagiarism.

d. Information about policies and procedures for plagiarism prevention, punishment and other authorship-related information needs to be more visible for students.

e. The existing digital storage for thesis needs to be improved through development of a more advanced online system that can be access by other HEIs. Universities need to focus on academic staff development by delivering training on intellectual property rights, plagiarism recognition and prevention.

f. Universities should include in their regulations an obligation for students to sign an authorship declaration not only for thesis but for all written works.

\section{Individual academics}

a. Universities need to start collecting students' written works (essays, project, etc., not just theses) in institutional repositories or just save them in digital form.

b. Every academic staff should provide guidance on requirements for citing, end referencing, policies and guidance about sanctions and consequences for plagiarism.

c. Academic staff need to pay more attention to providing students with guidance on proper academic writing. As Carroll and Appleton (2001) suggest, lecturers should create an intolerant culture around plagiarism by involving and engaging students through challenging tasks and being open to students' opinions and ideas too.

\section{Conclusion}

It is very important to emphasise that HEIs in Kosovo are new institutions that have been established for less than a decade, besides the University of Pristina, which is almost 50 years old. Nevertheless, the above analyses demonstrate that there is no harmony between the legal documents of HEIs on one side, and between copyright law and other related rights and the documents adopted by universities on the other side. Based on the anecdotal evidence collected, the authors conclude that no public university currently has sufficient and clear regulations that prevent plagiarism, let alone private colleges, which operate largely unchecked. Even in cases where documentation does exist, the focus is on preventing plagiarism amongst academic staff rather than students. Existing documents, policies and legislation do not outline clearly the punitive measures for students who plagiarise. In the case of UKZ and UHZ specifically, plagiarism is not clearly defined in either of their Code of Ethics documents, therefore making it difficult to take action against those who plagiarise.

\section{Quality assurance}

While Quality Assurance is the focus of all public universities in Kosovo, improvement, and the will to improve, is slow. Despite this, public universities have managed the situation well, and have established good mechanisms for quality assurance. Besides hiring dedicated personnel for this position, the Quality Assurance mechanism has also been supported by some very well-known professors. 


\title{
Teaching and training
}

Unfortunately, there is no clear policy on the approach to be followed in the future for the plagiarism prevention. So far, both universities have foreseen the application of two approaches: punitive measures, and preventive measures by educating students. However, neither measures are clearly addressed in the two universities' documents, which leaves a gap with regard to implementation. Staff training, subjects, courses, student training, and other awareness raising measures not to plagiarize are inadequate and need to be developed further, in order to better detect, deter and take measures against those who plagiarise. Our anecdotal research suggests that there are still no debates or workshops on plagiarism organised by either university.

\section{Digital detecting tools}

It is clear that relevant software for detecting plagiarism is a crucial element not only for these two universities but for the whole of Kosovo. It is difficult to detect plagiarism if students translate from English, for example, let alone other foreign languages. Another issue is that professors are overloaded with lecturing and do not have enough time to improve the situation. Time is one of the crucial issues which, together with the high number of students, makes it impossible for professors to closely examine students' work for plagiarism.

\section{Endnotes}

${ }^{1}$ Personal Communications with Rectors of the University of Haxhi Zeka in Peja and University of Kadri Zeka in Gjilan, 15-16 July 2018.

\begin{abstract}
Abbreviations
AIAHEl: Administrative Instruction of Higher Education Institutions; BA: Bachelor of Arts; CE: Code of Ethic of the University of Haxhi Zeka; CoE: Code of Ethics of the University of Kadri Zeka; CRK: Constitution of the Republic of Kosovo; ECTS: European Credit Transfer and Accumulation System; ENQA: European Network of Quality Assurance; FAITH: Increasing the Financial Autonomy and Accountability at Public Higher Education Institutions in Kosova; HEl: Higher Education Institutions; ICT: Information Communication Technology; KAA: Kosovo Accreditation Agency; LCRR: Law on Copyright and Related Rights; LHE: Law on Higher Education; MA: Master of Arts; MEST: Ministry of Education, Science and Technology; NLK: National Library of Kosovo; PhD: Philosophy of Doctorate; RBS: Regulation on Bachelor Studies; RCE: Regulation on Code of Ethics; RDS: Regulation on Doctoral Studies; RMDP: Regulation on Measures and Disciplinary Procedures; RMS: Regulation on Master Studies; SPHE: Strategic Plan on Higher Education; SPHERE: Support to the Internationalization of Higher Education System; SUHZ: Statute of the University of Haxhi Zeka; SUP: Statute of the University of Prishtina; SUPZ: Statute of the University of Prizren; TSPUGJ: Temporary Statute of the University of Gjakova; TSPUM: Temporary Statute of the University of Mitrovica; TSUASF: Temporary Statute of the University of Applied Science of Ferizaj; TSUKZ: Temporary Statute of the University of Kadri Zeka; UHZ: University of Haxhi Zeka; UKZ: University of Kadri Zeka
\end{abstract}

\section{Authors' contributions}

$\mathrm{DL}$ collected and analyzed the legal documents and measures undertaken by the University of Kadri Zeka as one of the case studies of the present manuscript, on preventing and fighting plagiarism. While SS as corresponding author has also collected and analyzed the legal documents and measures undertaken by the University of Haxhi Zeka as the second case studies, on preventing and fighting plagiarism. DL and SS has prepared together all other parts of the manuscript (abstract, introduction, literature review, discussion, recommendations, conclusion and references). TM has done editing of the paper and huge contribution in structuring and clarifying whole sections of it. All authors read and approved the final manuscript.

\section{Authors' information}

Dukagjin Leka is professor of subjects: European Law and Legislation, Public International Law, Private International Law, International Organizations and International Human Rights Law. He is serving at the same time also as Vice Rector for International Relations at University "Kadri Zeka", Gjilan. He has very long experience (around 17 years) working in an international environment (UNMIK-United Nations Mission in Kosovo and EULEX-European Rule of Law Mission in Kosovo). During his studies, he has been participating in very different international programs and trainings, which have prepared him for his future career. He has published several articles, and some of them are also for academic integrity. His education consists of Doctoral studies, obtained at University of Tirana, Institute of European Studies, Doctoral Programme "European Studies and European Integration" - Legislation and European Institutions with the Thesis: "European Union Rule of Law Mission in Kosovo - EULEX", where he received the title in 2015 as Doctor of 
Science of European Legislation and Institutions. He finished his Master Degree in International Law at University of Prishtina, Law Faculty, Masters Program in International Law, where he received the title as Master of Sciences of International Law with Master Thesis "United Nations as an Organization for Maintaining Peace and Security - Collective Security according to U.N.). Professor Leka has two faculties obtained at University of Prishtina, Philosophic Faculty Department of Political Sciences and Public Administration, where he received the title as Bachellor of Political Sciences and as well he graduated in Law Faculty at University of Prishtina, where he received the title - Lawyer (4 year studies). His research interests include Academic integrity, International Law, European Law, European Institutions and European Integration, International organizations, International Human Rights Law, International Relations, Democracy, Comparative Law, Comparative Politics, etc. Sabiha Shala teaches International and European Law and at the same time serves as Vice-Rector for Academic Affairs and Research at the University of "Haxhi Zeka" Peja, Kosovo. She is also a part time professor at the European School of Law and Governance. Formerly, Shala served as Chief Executive officer in the Agency for European Integration at the Kosovo Prime Minister Office, where she worked as a consultant on various projects with different international organizations such as: EU, UNHCR, UNDP, and OSCE. She obtained a Ph.D. from University of Nice Sophia-Antipolise in France. She holds an LL.M in International and European Law from University of Riga, Latvia as well as an additional specialization in the field of diplomacy obtained from the Diplomatic Academy of Vienna. Her research interests include Academic integrity, European Integration, international law, International organizations and regimes, ect. Tina Morganella is a freelance writer and copy editor with an MPhil in creative writing from the University of Adelaide, Australia. Tina has published short fiction, memoir and travel literature and has most recently appeared in in Rush (US), STORGY Magazine (UK), and Tulpa Magazine (Australia). She also has nonfiction articles published in the Australian press (The Big Issue, The Australian, The Adelaide Advertiser). Tina also has a long history in education administration and a personal interest in academic integrity. She is currently employed at the Entrepreneurship, Commercialisation and Innovation Centre at the University of Adelaide.

\section{Ethics approval and consent to participate}

We confirm that this manuscript has not been published elsewhere and is not under consideration by another journal.

\section{Consent for publication}

All authors have approved the manuscript and agree with its submission for publication to the International Journal for Educational Integrity (Springer Nature).

\section{Competing interests}

The authors declare that they have no competing interests.

\section{Publisher's Note}

Springer Nature remains neutral with regard to jurisdictional claims in published maps and institutional affiliations.

\section{Author details}

${ }^{1}$ University of Haxhi Zeka, Peja, Kosovo, Albania. ${ }^{2}$ University of Kadri Zeka, Gjilan, Kosovo, Albania.

Received: 22 September 2018 Accepted: 21 November 2018

Published online: 27 December 2018

\section{References}

AIAHEI (2017) Administrative Instruction for the Accreditation of Higher Education Institutions in the Republic of Kosovo no 09/2017. https://masht.rks-gov.net/uploads/2017/08/pdfjoiner_1.pdf. Accessed 8 June 2018

Annane D, Annane F (2012) Plagiats dans les facultés de médecine, et leur prevention [plagiarism in medical schools and their prevention]. La Presse Medicale https://doi.org/10.1016/j.lpm.2012.02.048

Atkinson D, Yeoh S (2008) Student and staff perceptions of the effectiveness of plagiarism detection software. Australas J Educ Technol 24(2):222-240

Bailey, J (2016) The top 10 plagiarism stories of 2016. Available via Ithenticate http://www.ithenticate.com/plagiarismdetection-blog/the-top-10-plagiarism-stories-of-2016\#.W3gZeOgzbIV. Accessed 12 July 2018

Berisha VB (2014) Survey on Public Perceptions of Corruption in the Education Sector. UNDP, Prishtinë http://rai-see.org/wpcontent/uploads/2015/05/2014-Report_UNDP_Opinion-Poll_Corruption-in-Education-ENG_1.pdf. Accessed 13 July 2018

Buja R (2013) Ministri Buja prezantoj të arritura dhe sfidat për vitin 2013 (Minister Buja presents the achievements and challenges for the year 2013). Available via MEST https://masht.rks-gov.net/article/ministri-buja-prezantoi-te-arriturat-dhesfidat-e-vitit-2013. Accessed 31 Aug 2018

Carroll J (2004) Deterring, detecting and dealing with plagiarism. Oxford: Brookes University Available via BROOKES https:// www.brookes.ac.uk/services/ocsld/resources/plagiarism.html. Accessed 4 Aug 2018

Carroll J, Appleton J (2001) A Good Practice Guide. Oxford: Brookes University. Available visa UNISA https://i.unisa.edu.au/siteassets/ staff/tiu/documents/plagiarism\%2D\%2D-a-good-practice-guide-by-oxford-brookes-university.pdf. Accessed 20 Aug 2018

CE (2014) Code of ethic in UHZ. UHZ, Pejë https://drive.google.com/file/d/OB1 c9UkiZAV3Za25mXzFWRUdEZDg/view. Accessed 20 July 2018

Comas FR, Sureda NJ (2010) Academic plagiarism: explanatory factors from students' perspective. Journal of Academic Ethics 8(3):217-232

Council of Europe (2017) Round table on codes of conduct in higher education. https:/www.coe.int/en/web/ethicstransparency-integrity-in-education/kosovo-/-/asset_publisher/26dPgZM79q3K/content/round-table-on-codes-of-conductin-higher-education?inheritRedirect=false. Accessed 20 June 2018

Craig R, Dalton D (2014) Developing a platform for a culture of honest inquiry and the academic construction of knowledge in first-year students. IJEl 10(1):56-69 https://www.ojs.unisa.edu.au/index.php/JJEl/article/viewFile/934/657. Accessed 16 July 2018 
CRK (2008) Constitution of the Republic of Kosovo. http://www.kryeministri-ks.net/repository/docs/Constitution1Kosovo.pdf. Accessed 24 Aug 2018

Embleton K, Helfer DS (2007) The plague of plagiarism and academic dishonesty. The Magazine for Database Professionals 15(6):23-26

ENQA (2014) Member's area. http://www.enqa.eu/wp-content/uploads/2015/01/Note-from-the-President_December-2014.pdf. Accessed 25 July 2018

ENQA (2018) ENQA Board welcomes two new members, kosovo agency designated member under review. https:/enqa.eu/index. php/enqa-board-welcomes-two-new-members-kosovo-agency-designated-member-under-review/. Accessed 25 July 2018

FAITH (2016) Increasing the Financial Autonomy and Accountability at Public Higher Education Institutions in Kosova -a European Union-funded TEMPUS Project. Available via TEMPUS-FAITH.EU http://www.tempus-faith.eu/content/mediainformation-new-financial-management-three-public-universities-republic-kosovo. Accessed 6 June 2018

Guraya SY, Guraya SS (2017) The confounding factors leading top plagiarism in academic writing and some suggested remedies: a systematic review. Systematic Review 67(5):767-772

KAA (2018a). Higher Education Institution. www.akreditimi-ks.org/new/index.php/en/download/higher-eduacion-institutions. Accessed 9 July 2018

KAA (2018b) Accreditation/List of Accredited Study Programmes. http://akreditimi-ks.org/docs/Downloads/Accreditation/ Accreditation_Public\%28082018\%29.pdf. Accessed 4 Aug 2018

LCRR (2007) Law on copyright and related rights. Available via GZK https://gzk.rks-gov.net/ActDocumentDetail.aspx?ActID= 2445. Accessed 20 June 2018

LCRR (2011) The Law No. 04/L-065 on Copyright and related rights. https://gzk.rks-gov.net/ActDocumentDetail.aspx? Act|D= 2787. Accessed 16 June 2018

LCRR (2016) Law no. 05/I-047 on amending and supplementing the law no.04/I-065 on copyright and related rights. https:// gzk.rks-gov.net/ActDocumentDetail.aspx?ActID=13022. Accessed 16 July 2018

LHE (2011) Law no. In: 04/I-037 on Higher Education in the Republic Kosovo http://masht.rks-gov.net/uploads/2015/06/02ligji-per-arsimin-e-larte-anglisht.pdf. Accessed 12 July 2018

Lindsay B (2016) Student plagiarism in universities: the scope of disciplinary rules and the question of evidentiary standards. International Journal of Law \& Education 1(3). http://www.anzela.edu.au/assets/ijle_vol_16.1_-_3_lindsay.pdf

LRPRK (2016) Law no. In: 05/I - 066 on the Regulated Professions in the Republic of Kosovo https://gzk.rks-gov.net/ ActDocumentDetail.aspx?Act|D=13072. Accessed 12 Aug 2018

Masic I (2012) Plagiarism in scientific publishing. World Med J 20(4):208-213. https://doi.org/10.5455/aim.2012.20.208-213

MEST (2018). Education Statistics in Kosovo 2017/2018. http://masht.rks-gov.net/uploads/2018/07/statistikat-e-arsimit-nekosove-2017-18_1.pdf. Accessed 2 July 2018

NLK (2018). National Library of Kosovo "Pjetër Bogdani". http://www.biblioteka-ks.org/. Accessed 23 Aug 2018

Okoche J, Michael M (2013) Plagiarism: the Cancer of East African University Education. Journal of Education and Practice. 4 (17):137-143. Available via IISTE http://www.iiste.org/Journals/index.php/JEP/article/view/7396/7531. Accessed 20 Aug 2018

RBS (2013) Regulation on Bachelor Studies. UKZ, Gjilan https://www.uni-gjilan.net/wp-content/uploads/2017/07/ RregullorePerStudimetThemeloreBacelor_FakultetiEkonom_622975.pdf. Accessed 9 July 2018

RBS (2016) Regulation no.193 on bachelor studies. Peja, UHZ

RCE (2016) Regulation No. 02/1388 for the Code of Ethics in UKZ. UKZ, Gjilan https://www.uni-gjilan.net/wp-content/uploads/ 2018/03/Rregullore-për-Kodin-e-Etikës-në-UKZ.pdf. Accessed 9 July 2018

RDS (2017) Regulation on doctoral studies. UHZ, Peja

RMDP (2014) Regulation on Measures and Disciplinary Procedures for Academic staff and Student of UKZ. https://www.uni-gjilan. net/wp-content/uploads/2015/03/Rregullore_p\%C3\%ABr_Masat_dhe_Procedur\%C3\%ABn_Disiplinore_p\%C3\%ABr_ Personelin_Akademik_dhe_Student\%C3\%ABt_948536.pdf (Albanian version). Accessed 9 July 2018

RMS (2016) Regulation no.192 on master studies. UHZ, Peja

SPHE (2016) Strategic Plan on Higher Education 2017-2021. https://masht.rks-gov.net/uploads/2017/02/20161006-kesp-20172021-1.pdf. Accessed 31 Aug 2018

SPHERE (2018) Higher Education in Kosovo Project and Support to the Internationalization of the Kosovo Higher Education System through the establishment of the Kosovo Students' Union. https://supporthere.org/page/higher-educationkosovo. Accessed 2 Aug 2018

Stabingis L, Šarlauskienè L, Čepaitienè N (2014) Measures for plagiarism prevention in students' written works: case study of ASU experience. Procedia - Social and Behavioral Sciences 110:689-699. https://doi.org/10.1016/j.sbspro.2013.12.913

SUHZ (2013) Statute of the University of "Haxhi Zeka" in Peja. https://drive.google.com/file/d/ OB1c9UkiZAV3ZTOJaTkRJLTVFMFk/view. Accessed 5 Aug 2018

SUP (2013) Statute of the University of Pristina. https://www.uni-pr.edu/inc/doc/statuti1.pdf. Accessed 16 Aug 2018

SUPZ (2013). Statute of the University of Prizen. https://uni-prizren.com/repository/docs/STATUTI_I_UNIVERSITETIT_TE_ PRIZRENIT_UKSHIN_HOTI_1_684621_938949.pdf. Accessed 5 Aug 2018

TSPUGJ (2013) Temporary Statute of Public University of Gjakova. https://www.uni-gjk.org/upload/dokumentet/99762Statuti\%20i\%20Perkohshem.pdf. Accessed 5 Aug 2018

TSPUM (2013) Temporary statute of the Public University of Mitrovica. UMIB. http://umib.net/wp-content/uploads/2015/10/ spum.pdf. Accessed 5 Aug 2018

TSUASF (2015) Temporary Statute of Public University of Applied Science in Ferizaj. http://www.ushaf.net/wp-content/ uploads/2016/10/STATUTI-I-P\%C3\%8BRKOHSH\%C3\%8BM-I-UNIVERSITETIT-T\%C3\%8B-SHKENCAVE-T\%C3\%8B-APLIKUARAN\%C3\%8B-FERIZAJ.pdf. Accessed 18 June 2018

TSUKZ (2013). Temporary Statute of the University of "Kadri Zeka"in Gjilan. https://www.uni-gjilan.net/wp-content/uploads/ 2017/06/Statuti_i_Përkoheshëm_i_Universitetit_Publik_të_Gjilanit_110471-1.pdf. Accessed 5 Aug 2018

UHZ (2018a) Syllabuses for the courses of study programes at the UHZ. Available via UHZ http://unhzeu/course/fakulteti-imenaxhimit-ne-turizem-hotelieri-dhe-mjedis/?arsim_course=menaxhment-ne-turizem-dhe-hotelieri\%20. Accessed 8 Aug 2018

UHZ (2018b) Study programs of economic faculty 2017/2018. Available via UHZ website https://unhz.eu/?arsim_course= fakulteti-i-biznesit-2. Accessed 10 July 2018 
UKZ (2018a) Syllabuses for the courses of study programmes at the UKZ. Available via UKZ https://www.uni-gjilan.net/ fakultetet/fakulteti-i-edukimit/programet-studimore/. Accessed 8 Aug 2018

UKZ (2018b) Study program 2017/2018. Gjilan: UKZ. Available via UKZ https://www.uni-gjilan.net/fakultetet/fakulteti-iedukimit/programet-studimore/. Accessed 19 July 2018

UP (2004) Statute of the University of Pristina. University of Prishtina, Prishtinë https://www.uni-pr.edu/inc/doc/statuti1.pdf. Accessed 16 Aug 2018

Vinod KR, Sandhya S, Kumar S, Harani A, Banji D, Banji JF (2011) Plagiarism- history, detection and Prevention Hygeia. Journal for Drugs and Medicins 3(1):1-4 http://www.hygeiajournal.com/downloads/Editorial/1597787464plagiarism.pdf. Accessed 2 July 2018

Wager E (2014) Defining and responding to plagiarism. Learned Publishing 27(1):33-42 https://doi.org/10.1087/20140105

Ready to submit your research? Choose BMC and benefit from:

- fast, convenient online submission

- thorough peer review by experienced researchers in your field

- rapid publication on acceptance

- support for research data, including large and complex data types

- gold Open Access which fosters wider collaboration and increased citations

- maximum visibility for your research: over $100 \mathrm{M}$ website views per year

At $\mathrm{BMC}$, research is always in progress.

Learn more biomedcentral.com/submissions 